\title{
Aplikasi Pupuk Organik Kotoran Ayam dan Jerami Padi pada Pertumbuhan dan Produksi Bawang Merah (Allium cepa L. var. bima curut)
}

\section{Application of Chicken Manure and Rice Straw on The Growth and Production of Shallots (Allium cepa L. var. bima curut)}

\author{
Mudlikatun Khasanah $^{1}$, Sri Widodo Agung Suedy ${ }^{2 *}$, Erma Prihastanti ${ }^{2}$ \\ ${ }^{1}$ Mahasiswa Program Studi Biologi, Departemen Biologi, Fakultas Sains dan Matematika, \\ Universitas Diponegoro \\ ${ }^{2}$ Departemen Biologi, Fakultas Sains dan Matematika, Universitas Diponegoro \\ J1. Prof Soedarto, SH, Tembalang, Semarang, Jawa Tengah, Indonesia \\ *Email: swasuedy@live.undip.ac.id
}

Diterima 30 Juli 2018 / Disetujui 8 Oktober 2018

\begin{abstract}
ABSTRAK
Salah satu varietas bawang merah lokal adalah bima curut dengan kemampuan adaptasi yang baik, ukuran umbi besar, dan jumlah anakan yang banyak. Optimasi peningkatan produksi bawang merah salah satunya melalui pemupukan menggunakan pupuk organik dari kotoran ayam dan jerami padi. Tujuan penelitian ini adalah mengetahui pengaruh pupuk organik dari bahan kotoran ayam dan jerami padi terhadap pertumbuhan dan produksi bawang merah. Rancangan penelitian yang digunakan adalah RAL (Rancangan Acak Lengkap), dengan 7 perlakuan yaitu: P0 (tanpa pupuk); P1 (pupuk anorganik); P2 (pupuk kotoran ayam:pupuk jerami, perbandingan 0:1); P3 (pupuk kotoran ayam:pupuk jerami, perbandingan 1:0); P4 (pupuk kotoran ayam:pupuk jerami perbandingan 1:1); P5 (Pupuk kotoran ayam:pupuk jerami, perbandingan 1:2); P6 (pupuk kotoran ayam:pupuk jerami, perbandingan 2:1); tiap perlakuan dengan 4 ulangan. Analisis data menggunakan Analysis of Variance dilanjutkan dengan uji Duncan's Multiple Range Test pada taraf signifikasi 95\%. Hasil penelitian menunjukkan bahwa penggunaan pupuk organik kotoran ayam dan jerami padi berpengaruh nyata meningkatkan pertumbuhan dan produksi bawang merah berupa: jumlah daun sebesar $41 \%$ dan tinggi tanaman sebesar $42 \%$, serta jumlah umbi/rumpun sebesar $41 \%$; jumlah umbi $/ \mathrm{m}^{2}$ sebesar $22 \%$; berat basah sebesar 35\%; dan berat kering sebesar $31 \%$ dibandingkan kontrol (P0).
\end{abstract}

Kata kunci: bawang merah, bima curut, kotoran ayam, jerami padi

\begin{abstract}
One of the local onion cultivars is bima curut with good adaptability, large bulb size, and a large number of tillers. Optimization of increasing onion production is one of them through fertilization using organic fertilizer from chicken manure and rice straw. The purpose of this study was to determine the effect of organic fertilizer from chicken manure and rice straw on the growth and production of shallots. The research design used was RAL (Completely Randomized Design), with 7 treatments, namely: P0 (without fertilizer); P1 (inorganic fertilizer); P2 (chicken manure: straw fertilizer, a ratio of 0: 1); P3 (chicken manure: straw fertilizer, a ratio 1: 0); P4 (chicken manure: a ratio of 1: 1 straw fertilizer); P5 (Fertilizer for chicken manure: straw fertilizer, a ratio of 1: 2); P6 (chicken manure: straw fertilizer, a ratio of 2: 1); each treatment with 4 replications. Data analysis using Analysis of Variance followed by Duncan's Multiple Range Test at 95\% significance level. The results showed that the use of organic fertilizer chicken manure and rice straw significantly affected the growth and production of shallots in the form of: the number of leaves by $41 \%$ and plant height by $42 \%$, as well as the number of tubers / clumps by $41 \%$; the number of tubers / $\mathrm{m} 2$ is $22 \%$; wet weight of $35 \%$; and dry weight of $31 \%$ compared to control (P0).
\end{abstract}

Keywords: shallots, bima curut, chicken manure, rice straw. 


\section{PENDAHULUAN}

Bawang merah (Alium cepa L.) merupakan komoditas hortikultura yang tergolong sayuran rempah (Sitepu, 2013). Kebutuhan nasional bawang merah menurut Elisabeth (2013) terus mengalami peningkatan seiring dengan laju pertambahan jumlah penduduk, sementara produksi bawang merah belum bisa mencukupi kebutuhan.bawang merah. Suwandi (2015) menyatakan laju produksi bawang merah sebesar 2,10 ton/ha dengan produksi tahun 2015 sebesar 1.233.984 ton per tahun sedangkan permintaan kebutuhan dalam negeri sebesar 1.308.887 ton per tahun. Data tersebut menunjukkan permintaan kebutuhan bawang merah lebih besar dibandingkan produksinya.

Salah satu cara untuk meningkatkan produksi adalah melalui pemupukan. Pemupukan dapat dilakukan dengan menggunakan pupuk organik dan anorganik (NPK). Supartha (2012) menyatakan penggunaan pupuk organik mampu menjaga keseimbangan lahan dan meningkatkan produktivitas lahan untuk meningkatkan hasil pertanian. Salah satu varietas bawang merah yang dibudidayakan petani adalah varietas lokal Brebes yaitu bima curut. Varietas memiliki warna merah cerah dengan jumlah anakan antara 3 sampai 22 anakan (Winarko, 2012). Menurut Basuki (2013) varietas lokal yang diusahakan petani di sentra produksi Cirebon dan Brebes sangat beragam, tetapi varietas bima curut sangat disukai konsumen, harga jual tinggi, serta pasarnya cukup luas. Menurut Kusmana (2013) bawang merah varietas bima curut banyak dibudidayakan karena memiliki daya adaptasi yang baik, ukuran umbi besar, aroma khas dan jumlah anakan banyak.

Bawang merah merupakan jenis sayuran yang dimanfaatkan umbinya. Pembentukan umbi bawang merah membutuhkan unsur hara makro dan mikro (Supartha, 2012). Unsur hara makro berperan dalam pembentukan dan struktur sel sedangkan unsur hara mikro berperan dalam metabolisme dan aktivitas enzim (Suwandi, 2015). Kelebihan penggunaan pupuk organik adalah memiliki kandungan unsur hara makro dan mikro yang lengkap, kehidupan organisme tanah terjaga, pelepasan hara organik dilakukan secara perlahan sehingga mencegah suplai hara yang berlebihan, memobilisasi hara yang sudah ada didalam tanah agar mudah diserap tanaman, dan memperbaiki sifat kimia tanah (Soenandar dan Tjachjono, 2012).

Pupuk organik kotoran ayam dapat menyediakan beberapa unsur hara makro serta mikro yang sangat dibutuhkan tanaman khususnya bawang merah (Soeryoko, 2011). Kotoran ayam memiliki kemampuan untuk meningkatkan kapasitas tukar kation (KTK) tanah. Kelebihan lain dari menggunakan pupuk kotoran ayam yaitu dapat membentuk senyawa kompleks dan bereaksi dengan ion logam sehingga mampu mengurangi ion-ion logam yang berpotensi menghambat penyediaan unsur hara seperti $\mathrm{Al}, \mathrm{Fe}$, dan $\mathrm{Mn}$ atau ion logam yang meracuni tanaman. Pupuk kotoran ayam yang berlebihan dapat memberikan dampak meracuni tanaman dan serangan penyakit tanaman. Salah satu unsur hara yang dapat memberikan ketahanan tanaman terhadap penyakit adalah silika (Si). Kandungan silika pada pupuk kandang ayam tergolong rendah, oleh karena itu diperlukan kombinasi dengan pupuk dari bahan organik lainnya. Salah satu bahan organik yang memiliki kandungan silika tinggi adalah berasal dari tumbuhan seperti jerami padi (Suwahyono, 2014).

\section{METODE PENELITIAN}

\section{Tempat dan Waktu}

Penelitian dilakukan di lahan persawahan Desa Mlaten, Kecamatan Mijen, Kabupaten Demak, Jawa Tengah dengan ketinggian tempat 0100mdpl dan tekstur tanah gromosol kelabu tua. Waktu penelitian dilaksanakan pada bulan Maret sampai Juli 2016.

\section{Persiapan Alat dan bahan}

Bibit bawang merah yang digunakan diseleksi terlebih dahulu. Bibit sudah melalui penyimpanan 3bulan dengan umur panen 60hari. Bibit yang dipilih berwarna merah cerah, padat dan tidak lunak saat dipegang. Bibit yang sudah dipilih kemudian ditimbang dengan berat seragam yaitu \pm $5 \mathrm{~g}$ dan dilakukan pemangkasan kira- kira 1/3-1/4 dari panjang umbi. Langkah selanjutnya adalah pembuatan pupuk kotoran ayam dan jerami dengan 
bantuan EM4 dosis 20ml yang dikomposkan selama 2bulan.

\section{Pemupukan}

Pemupukan dilakukan seminggu sebelum penanaman pada lahan berukuran $1 \times 7 \mathrm{~m}$ dengan tinggi bedengan $\pm 70 \mathrm{~cm}$. Sebelum pemupukan dilakukan pembalikan tanah dengan cara dicangkul sedalam $20-40 \mathrm{~cm}$. Pupuk yang digunakan dianalisis $\mathrm{C} / \mathrm{N}$ rasionya, $\mathrm{C} / \mathrm{N}$ rasio kotoran ayam 7,5 dan $\mathrm{C} / \mathrm{N}$ rasio pupuk jerami padi $8 . \mathrm{C} / \mathrm{N}$ rasio pupuk sudah hampir mendekati $\mathrm{C} / \mathrm{N}$ rasio tanah $(\mathrm{C} / \mathrm{N}$ rasio tanah 10-12) sehingga sudah siap digunakan.

\section{Pemeliharaan Tanaman}

Pemeliharaan tanaman yaitu pengairan, penyiangan, dan pemberantasan hama. Pengairan dilakukan dengan cara menyirami petak tanam sebanyak 2 kali sehari sampai tanah basah pada semua perlakuan hingga umur 50hari. Penyiangan dilakukan tiap tujuh hari selama pertumbuhan bawang merah. Hama yang menyerang bawang merah berupa ulat grayak. Pengendalian hama dilakukan dengan menggunakan bahan alami berupa cairan hasil seduhan tembakau.

\section{Pemanenan}

Pemanenan dilakukan pada umur 60HST (Hari Setelah Tanam) dengan ciri tanaman: cukup tua dengan $60-90 \%$ batang telah kering dan daun menguning, umbi lapis terlihat padat berisi dan sebagian tersembul ke permukaan dengan warna kulit mengkilap dan memerah.

\section{HASIL DAN PEMBAHASAN}

\section{Pertumbuhan}

Hasil uji ANOVA dan DMRT pada taraf kepercayaan 95\% menunjukkan bahwa pemberian pupuk organik kotoran ayam dan jerami padi berpengaruh terhadap pertumbuhan yang berupa jumlah daun dan tinggi tanaman bawang merah umur 42HST pada Tabel 1 berikut ini.

Tabel 1. Hasil analisis pengaruh pemberian pupuk organik kotoran ayam dan jerami padi terhadap jumlah daun dan tinggi tanaman bawang merah varietas bima curut umur 42HST

\begin{tabular}{ccc}
\hline Perlakuan & Jumlah Daun per Rumpun (Helai) & Tinggi Tanamanan $(\mathrm{cm})$ \\
\hline $\mathrm{P}_{0}$ & $9,45^{\mathrm{c}}$ & $22,93^{\mathrm{d}}$ \\
$\mathrm{P}_{1}$ & $11,80^{\mathrm{b}}$ & $26,63^{\mathrm{c}}$ \\
$\mathrm{P}_{2}$ & $12,00^{\mathrm{ab}}$ & $28,00^{\mathrm{bc}}$ \\
$\mathrm{P}_{3}$ & $12,20^{\mathrm{ab}}$ & $28,00^{\mathrm{bc}}$ \\
$\mathrm{P}_{4}$ & $13,33^{\mathrm{a}}$ & $32,50^{\mathrm{a}}$ \\
$\mathrm{P}_{5}$ & $12,75^{\mathrm{ab}}$ & $28,80^{\mathrm{b}}$ \\
$\mathrm{P}_{6}$ & $12,25^{\mathrm{ab}}$ & $28,17^{\mathrm{bc}}$ \\
\hline
\end{tabular}

\section{Keterangan:}

Angka dengan superkrip yang berbeda pada baris yang sama menunjukkan perbedaan yang nyata antar perlakuan P0 (tanpa pupuk); P1 (pupuk anorganik); P2 (pupuk kotoran ayam:pupuk jerami, perbandingan 0:1); P3 (pupuk kotoran ayam:pupuk jerami, perbandingan 1:0); P4 (pupuk kotoran ayam:pupuk jerami perbandingan 1:1); P5 (Pupuk kotoran ayam:pupuk jerami, perbandingan 1:2); P6 (pupuk kotoran ayam:pupuk jerami, perbandingan 2:1)

Pemberian jenis pupuk berpengaruh meningkatkan jumlah daun dan tinggi tanaman jika dibandingkan dengan $\mathrm{P}_{0}$ (kontrol). Rata-rata pada jumlah daun yang memberikan hasil tertinggi diperoleh pada perlakuan P4 sebesar 13,33helai dan memberikan persentase kenaikan sebesar $41 \%$. Hasil tertinggi pada rata-rata tinggi tanaman diperoleh pada perlakuan $\mathrm{P} 4$ sebesar $32,50 \mathrm{~cm}$ dan memberikan persentase kenaikan sebesar $42 \%$. Pemberian jenis pupuk yang memberikan hasil tertinggi pada semua parameter pertumbuhan diperoleh pada perlakuan P4 dengan kombinasi pupuk kotoran ayam: pupuk jerami padi (1:1) berdasarkan dosis anjuran. 
Salah satu faktor yang mempengaruhi pertumbuhan adalah ketersediaan hara. Perlakuan yang menunjukkan hasil optimal pada pertumbuhan tanaman adalah P4. Perlakuan dosis kombinasi P4 menunjukkan hasil tertinggi pada pertumbuhan tanaman, apabila dosis ditambah pupuk kotoran ayam dan jerami padi (P5 atau P6) atau dosis pemupukan dikurangi (P0, P2, P3) maka hasil pertumbuhan menurun. Menurut Lumbangaol (2011) pertumbuhan yang maksimal dihasilkan dari pemupukan yang optimal. Pemupukan optimal adalah pemupukan yang dosisnya tepat, apabila kadar nutrisi melebihi ambang batas, sebagian tanaman akan menunjukkan gejala penyimpangan pertumbuhan berupa keracunan atau gangguan penyerapan antar beberapa nutrisi.

Jenis hara esensial yang dibutuhkan tanaman untuk pertumbuhan yaitu unsur hara makro $(\mathrm{N}, \mathrm{P}, \mathrm{K})$ dan mikro $(\mathrm{Cu}, \mathrm{Mn}, \mathrm{Zn}, \mathrm{Si}, \mathrm{Fe})$. Pemberian pupuk organik dari kotoran ayam dan jerami padi diduga dapat meningkatkan kapasitas tukar kation (KTK) yang berpengaruh pada pertumbuhan tanaman. KTK merupakan salah satu indikator kesuburan tanah. Tanaman menyerap ion dalam bentuk kation. Anisyah dkk (2014) menyatakan bahwa pemberian pupuk organik dapat mengurangi keasaman tanah. Tanah asam banyak mengandung logam yang mengikat unsur hara $\mathrm{P}$ sehingga lebih sulit diserap tanaman. Unsur hara $P$ merupakan usur esensial dalam pembentukan albumin, nukleoprotein yang menyusun sel sehingga kekurangan unsur $\mathrm{P}$ dapat mengganggu pertumbuhan tanaman.

Pengamatan pertumbuhan tanaman juga dapat dilihat dari kondisi fisik bawang merah melalui warna daun dan rebah daun. Perlakuan P0 (kontrol) memiliki warna daun lebih kuning, pucat dan rebah daun yang lebih tinggi dibandingkan dengan perlakuan menggunakan pupuk. Perlakuan dengan tambahan pupuk (P1, P2, P3, P4, P5, P6) menunjukkan warna daun yang lebih hijau. Warna daun yang menguning sebelum waktu panen diduga tanaman mengalami gejala defisiensi unsur hara.

\section{Produksi}

Hasil uji ANOVA dan DMRT pada taraf kepercayaan 95\% menunjukkan bahwa pemberian pupuk organik kotoran ayam dan jerami padi berpengaruh terhadap produksi yang berupa jumlah umbi $/ \mathrm{m}^{2}$, jumlah umbi per rumpun, berat basah, dan berat kering tanaman bawang merah (Tabel 2). Pemberian pupuk kotoran ayam dan jerami padi cenderung meningkatkan parameter produksi yang dipanen pada 60 HST. Pemberian kombinasi pupuk berpengaruh meningkatkan semua parameter penelitian jika dibandingkan dengan P0 (kontrol). Rata-rata jumlah umbi per rumpun yang memberikan hasil tertinggi diperoleh pada perlakuan diperoleh pada perlakuan P0 sebesar 8,00 umbi sehingga persentase kenaikan jumlah umbi per rumpun sebesar $41 \%$. Hasil tertinggi rata-rata jumlah umbi $/ \mathrm{m}^{2}$ diperoleh pada perlakuan P4 sebesar 898,00 umbi dengan persentase kenaikan jumlah umbi per $\mathrm{m}^{2}$ sebesar $22 \%$. Rata-rata berat basah tertinggi diperoleh pada perlakuan P2 sebesar 22,60g dengan kenaikan berat basah per rumpun sebesar 35\%. Rata-rata berat kering tertinggi diperoleh pada perlakuan P4 sebesar 19,40g dengan sehingga presentase kenaikan berat kering per rumpun sebesar $31 \%$.

Salah satu faktor yang menentukan produksi adalah pertumbuhan suatu tanaman. Pertumbuhan tanaman yang berjalan dengan baik mendukung produksi agar maksimal. Salah satu hasil pertumbuhan vegetatif tanaman adalah pembentukan umbi. Keberhasilan budidaya bawang merah dapat dilihat dari kemampuan tanaman dalam memproduksi umbi. Jumlah umbi paling banyak ditunjukkan pada perlakuan tambahan pupuk kotoran ayam dan jerami padi. Menurut Ismunadji (2006), selain unsur hara mikro, pembentukan umbi lebih banyak ditentukan oleh unsur hara makro berupa nitrogen $(\mathrm{N})$ dan potassium (K) dengan dosis yang sesuai. Pengamatan pertumbuhan menunjukkan P4 merupakan dosis yang paling optimal karena apabila dosis ditambah (P5, P6) atau dikurangi (P2, P3) dapat menurunkan hasil pada parameter pertumbuhan. Hal ini juga berpengaruh pada parameter produksi.

Parameter produksi yang paling optimal diperoleh pada perlakuan P4. Menurut Nugroho (2013) pemberian dosis pupuk adalah hal yang perlu diperhatikan dalam budidaya tanaman. 
Pemberian pemupukan yang berlebihan mengakibatkan ledakan suplai hara yang berlebih dan terbuang karena tanaman hanya menyerap hara sesuai dengan kebutuhan, bahkan pada taraf selanjutnya kejenuhan hara hanya akan meracuni tanaman. Pemberian hara yang rerlalu sedikit juga mempengaruhi tanaman karena kebutuhan hara kurang terpenuhi sehingga menunjukkan geljala defisiensi hara.

Tabel 2. Hasil analisis pengaruh pemberian pupuk organik kotoran ayam dan jerami padi terhadap produksi berupa jumlah umbi $/ \mathrm{m}^{2}$, jumlah umbi per rumpun, berat basah, dan berat kering tanaman bawang merah varietas bima curut umur 60HST

\begin{tabular}{ccccc}
\hline Perlakuan & $\begin{array}{c}\text { Jumlah } \\
\text { Umbi/Rumpun } \\
\text { (Umbi) }\end{array}$ & $\begin{array}{c}\text { Jumlah } \\
\text { Umbi/m2 } \\
(\text { Umbi) }\end{array}$ & $\begin{array}{c}\text { Berat } \\
\text { Basah/Rumpun (g) }\end{array}$ & $\begin{array}{c}\text { Berat } \\
\text { Kering/Rumpun (g) }\end{array}$ \\
\hline P0 & $8,00^{\mathrm{b}}$ & $734.50^{\mathrm{f}}$ & 16,75 & 14,80 \\
P1 & $8,75^{\mathrm{b}}$ & $813,50^{\mathrm{e}}$ & 16,80 & 14,95 \\
P2 & $8,75^{\mathrm{b}}$ & $822,25^{\mathrm{d}}$ & 22,60 & 16,90 \\
P3 & $8,75^{\mathrm{b}}$ & $834,50^{\mathrm{c}}$ & 21,15 & 16,20 \\
P4 & $11,25^{\mathrm{a}}$ & $898,00^{\mathrm{a}}$ & 19,60 & 19,40 \\
P5 & $9,25^{\mathrm{b}}$ & $854,75^{\mathrm{b}}$ & 18,30 & 17,35 \\
P6 & $8,75^{\mathrm{b}}$ & $825,50^{\mathrm{d}}$ & 16,76 & 15,20 \\
\hline
\end{tabular}

Keterangan:

Angka dengan superkrip yang berbeda pada baris yang sama menunjukkan perbedaan yang nyata antar perlakuan P0 (tanpa pupuk); P1 (pupuk anorganik); P2 (pupuk kotoran ayam:pupuk jerami, perbandingan 0:1); P3 (pupuk kotoran ayam:pupuk jerami, perbandingan 1:0); P4 (pupuk kotoran ayam:pupuk jerami perbandingan 1:1); P5 (Pupuk kotoran ayam:pupuk jerami, perbandingan 1:2); P6 (pupuk kotoran ayam:pupuk jerami, perbandingan 2:1)

Kaya (2013) menyatakan bahwa nitrogen digunakan untuk meningkatkan laju fotosintat dengan meningkatkan sintesa protein pada sel tanaman terutama pada pembentukan umbi. Pembentukan lapisan daun yang membesar terbentuk dari mekanisme kerja unsur $\mathrm{N}$ yang membentuk asam nukleat. Asam nukleat berperan dalam inti sel pada proses pembelahan sel sehingga pembentukan lapisan daun dapat terbentuk dengan baik sehingga berkembang menjadi umbi bawang merah. Hal ini sesuai dengan pendapat. Unsur lain yang berperan dalam pembentukan umbi adalah kalium (K). Kandungan kalium pada jerami lebih banyak dibandingkan dengan kotoran ayam. Kalium pada kotoran ayam sebesar $0,4 \%$ sedangkan pada jerami padi $1,59 \%$. Kalium merupakan unsur yang paling banyak diserap karena tanaman hanya dapat menyerap unsur hara dalam bentuk kation $\left(\mathrm{K}^{+}\right)$.

Kalium berfungsi dalam pembentukan gula dan pati sintesis protein, katalis bagi reaksi enzimatis, penetral asam organik serta berperan dalam pertumbuhan jaringan meristem. Hal ini sesuai dengan pendapat Pasaribu (2012), bahwa kalium merupakan unsur hara makro yang berpengaruh pada pembentukan organ tanaman berupa umbi, daun dan jaringan meristem. Kalium berperan sebagai katalis enzimatis pada metabolisme serta pembentukan gula dan pati pada sintesis protein sehingga membantu pembentukan dan pembesaran organ tanaman.

Parameter berat basah dengan hasil tertinggi terletak pada perlakuan P2 sedangkan berat kering tertinggi terletak pada perlakuan $\mathrm{P} 4$. Hal ini kemungkinan dikarenakan pada saat penimbangan berat basah tanaman pada perlakuan P2 memiliki kondisi fisik tanaman yang masih segar pada 60HST sehingga kandungan airnya masih tinggi. Kandungan air yang keluar saat pengeringan menyebabkan sel mengkerut sehingga berat keringnya menjadi lebih rendah. Hal ini berbeda dengan keadaan perlakuan $\mathrm{P} 4$ pada saat pemanenan (60HST) yang memiliki kondisi fisik yang sudah tidak segar seperti perlakuan P2. Perlakuan P4 memiliki kondisi fisik sudah mengering pada bagian daunnya sehingga kadar air dalam sel sudah keluar pada saat penimbangan berat basah. Hal ini menyebabkan pada saat 
penimbangan berat kering perlakuan $\mathrm{P} 4$ memiliki penyusutan bobot yang lebih sedikit karena sudah berupa akumulasi senyawa yang sebenarnya.

Rahmah (2013) menyatakan bahwa pupuk kotoran ayam dengan dosis 40 ton/ha pada bawang merah mampu meningkatkan data berat basah dan berat kering tanaman dibandingkan dengan kontrol karena memberikan unsur yang dibutuhkan untuk pembelahan dan perpanjangan sel tanaman. Pemberian jenis pupuk juga dapat dilihat pada hasil produksi bawang merah yang berupa umbi. Berdasarkan hasil pengamatan warna umbi diperoleh perlakuan kontrol (P0) memiliki warna umbi yang lebih pucat dibandingkan dengan perlakuan pada tanaman yang diberi pupuk (P1, P2, P3, P4, P5). Perlakuan dengan pemberian pupuk memiliki warna umbi merah cerah dan mengkilap. Mayun (2011) menyatakan bahwa iklim, pemupukan, pengairan dan tanah merupakan faktor penentu dalam produktivitas maupun kualitas umbi bawang merah. Bawang merah yang memiliki kualitas prima dapat dilihat dari warna, kepadatan, bentuk umbi, serta ketahanan umbi terhadap suhu.

\section{KESIMPULAN}

Penggunaan kombinasi pupuk kotoran ayam dan pupuk jerami padi berpengaruh meningkatkan pertumbuhan dan produksi tanaman bawang merah (Allium cepa L. var. bima curut). Pemberian pupuk kotoran ayam dan pupuk jerami padi yang optimal untuk meningkatkan pertumbuhan dan produksi bawang merah (Allium cepa L. var. bima curut) adalah perlakuan $\mathrm{P} 4$ kombinasi kotoran ayam: jerami padi (1:1).

\section{DAFTAR PUSTAKA}

Anisyah, Fitri dan R. Sipayung. 2014. Pertumbuhan dan Produksi Bawang Merah dengan Pemberian Berbagai Pupuk Organik. Jur. Onl. Agroekotek. 2(2): 482-496.

Basuki, S.R. 2013. Penelitian Daya Hasil Dan Preferensi Petani Terhadap Varietas Bawang Merah Lokal Dari Berbagai Daerah. Jur. Pertanian. 3(2): 24-31.

Elisabeth, D. 2013. Pengaruh Pemberian Berbagai Komposisi Bahan Organik pada
Pertumbuhan dan Hasil Bawang Merah (Allium ascalonicum L.). Jur. Prod.

Tanaman. 1(3): 21-29.

Ismunadji. 2006. Morfologi dan Fisiologi Tanaman. Gramedia, Jakarta.

Kaya. 2013. Pengaruh Kompos Jerami dan Pupuk NPK Terhadap N Tersedia Tanah Serapan N, Pertumbuhan, dan Hasil Padi Sawah (Oryza sativa L). Agrologia. 2.(1): 43-50.

Kusmana. 2013 Uji Adaptasi Lima Varietas Bawang Merah Asal Dataran Tinggi dan Medium Pada Ekosistem Dataran Rendah Brebes. Agrologia. 3(5): 117-125.

Lumbangaol, P., 2011. Pedoman Pembuatan Dosis Pupuk Kelapa Sawit. Department Musim Mas Group, Medan.

Mayun, A. 2011. Efek Mulsa Jerami Padi dan Pupuk Kandang Sapi terhadap Pertumbuhan dan Hasil Bawang Merah (Allium Ascalonicum L.) di Daerah Pesisir. Agritrop. 26(1): 33-40.

Nugroho, T. 2013. Perbaikan Teknologi Produksi Umbi Benih Bawang Merah dengan Ukuran Umbi Benih Aplikasi Zat Pengatur Tumbuh dan Unsur Hara Mikroelemen. Jur. Hortikult., 14(1): 1-2.

Pasaribu. 2012. Pengaruh Penggunaan Pupuk Anorganik dan Organik terhadap Pertumbuhan dan Produksi Bawang Merah (Allium ascalonicum L.). Jur. Agrium. 17(2): 108-113.

Rahmah, A. 2013. Pertumbuhan Dan Produksi Bawang Merah (Allium Ascalonicum L.) Dengan Pemberian Pupuk Kandang Ayam Dan Em4 (Effective Microorganisms4). Jur. Onl. Agroekotek.. 1(4):952-962.

Sitepu, B.H. 2013. Respon pertumbuhan dan Produksi Bawang Merah (Allium ascalonicum L. Var. Tuk Tuk) Asal Biji terhadap Pemberian Pupuk Kalium dan Jarak Tanam. Jur. Onl. Agoekotek, 1(3): 711-724. 
Soenandar M. dan Tjachjono R. 2012. Membuat Petisida Nabati. AgroMedia Pustaka, Jakarta.

Soeryoko, H. 2011. Kiat Pintar Memproduksi Kompos dengan Pengurai Buatan Sendiri. Lily Publisher, Yogyakarta.

Supartha.2012. Pengaruh Komposisi Media Semai Lokal terhadap Pertumbuhan Bibit Bawang Merah Asal Biji (true shallot seed). Jur. Ilmu-ilmu Hayati dan Fisik, 12(1): 22-29.

Suwandi. 2015. Peran media Tanam dan Dosis Pupuk Urea, SP-36, $\mathrm{KCl}$ terhadap
Pertumbuhan Bawang Daun (Allium

fistolusumL.) dalam Polybag. Jur. Agonobis,3(5): 17-21.

Suwahyono, Untung. 2014. Petunjuk Praktis Penggunaan Pupuk Organik Secara Efektif Dan Efisien. Jakarta: Penebar Swadaya.

Winarko. 2012. Pengaruh Periode Vernalisasi Terhadap Pembungaan dan Hasil Biji Beberapa Varietas Bawang Merah (Allium ascalonicum L.). Skripsi. Fakultas Pertanian Universitas Sebelas Maret, Surakarta. 